\title{
The biological relevance of thyroid hormone receptors in immortalized human umbilical vein endothelial cells
}

\author{
M J M Diekman, B Zandieh Doulabi, M Platvoet-ter Schiphorst, \\ E Fliers, $\mathrm{O}$ Bakker and $\mathrm{W} \mathbf{M}$ Wiersinga
}

Department of Endocrinology, Academic Medical Centre, Meibergdreef 9, 1105 AZ Amsterdam, The Netherlands

(Requests for offprints should be addressed to O Bakker, Department of Endocrinology, F5-171, Academic Medical Centre, Meibergdreef 9,

1105 AZ Amsterdam, The Netherlands; Email: O.Bakker@AMC.UVA.NL)

\begin{abstract}
The gene expression of thyroid hormone receptors (TR) in ECRF24 immortalized human umbilical vein endothelial cells (HUVECs) was investigated at both the mRNA and the protein level. Endothelin-1 (ET-1) and von Willebrand factor (vWF) production were measured in response to triiodothyronine $\left(\mathrm{T}_{3}\right)$ administration. A realtime PCR technique was used to quantify the presence of mRNAs encoding for the different isoforms of the TR. The binding of $\mathrm{T}_{3}$ to nuclear TRs was studied in isolated endothelial cell nuclei by Scatchard analysis. Expression of TR at the protein level was investigated by immunocytochemistry and Western blotting using TR-isoformspecific polyclonal rabbit antisera. ET-1 and vWF were measured in cell supernatants with a two-site immunoenzymatic assay. Scatchard analysis yielded a maximum binding capacity of $55 \mathrm{fmol} \mathrm{T} / \mathrm{mg}$ DNA ( \pm 200 sites/
\end{abstract}

cell) with a $K_{\mathrm{d}}$ of $125 \mathrm{pmol} / 1$. Messenger RNAs encoding for the TR $\alpha 1$ and the $\operatorname{TR} \alpha 2$ and the $\operatorname{TR} \beta 1$ were observed. The approximate number of mRNA molecules per cell was at least 50 molecules per cell for TR $\alpha 1$, five for $\operatorname{TR} \alpha 2$ and two for $\operatorname{TR} \beta 1$. Immunocytochemistry revealed (peri)nuclear staining for TR $\beta 1, T R \alpha 1$ and TR $\alpha 2$. ET-1 and vWF secretion did not increase upon addition of $\mathrm{T}_{3}\left(10^{-10}-10^{-6} \mathrm{M}\right)$. Immortalized ECRF24 HUVECs express TR, but at low levels. The number of TRs per endothelial cell is probably too low to be functional and no change in ET-1 or vWF production was found after addition of $T_{3}$. Therefore we conclude that the genomic effects of $T_{3}$ are unlikely to occur in these immortalized HUVECs.

Journal of Endocrinology (2001) 168, 427-433

\section{Introduction}

Endothelial cells appear to function as a large endocrine organ in the human body (Vane et al. 1990). Little is known about the interaction of thyroid hormones with endothelial cells. This is of potential interest because endothelial cell dysfunction is involved in cardiovascular disease (Cines et al. 1998) and thyroid dysfunction is a frequently occurring condition with an increased risk for cardiovascular complications (Polikar et al. 1993). It would therefore be of interest to have a model system in which to study the interaction of thyroid hormone with endothelial cells. The main action of thyroid hormone is thought to be mediated by affecting gene expression by binding of triiodothyronine $\left(\mathrm{T}_{3}\right)$ to its nuclear thyroid hormone receptor (TR), which in turn binds to a specific DNA element regulating transcription (Lazar 1993). At least four isoforms of the TR are known, namely $\alpha 1, \alpha 2, \beta 1$ and $\beta 2$, which are present in different tissues in different relative concentrations. TR $\alpha 2$ is a splicing variant of the $\alpha$ gene that is not able to bind $\mathrm{T}_{3}$ but may act in a dominant- negative fashion on $\mathrm{T}_{3}$-dependent gene expression. TR $\alpha 1$ and TR $\beta 1$ usually act in a positive fashion.

A few studies, in which endothelial cells from various sources were studied with different probes and techniques, have reported on the presence of TRs in these cells and on postreceptor effects. Immunofluorescence studies, using polyclonal antibodies raised in mice against bovine TRs, showed both cytoplasmic and perinuclear staining in cultured bovine aortic cells, sinusoids, liver tissue and intima of large vessels in spleen (Sellitti et al. 1985). Also in bovine aortic endothelial cells mRNAs for TR $\alpha 1$, TR $\alpha 2$ and TR $\beta 1$ were found using Northern blot and S1 nuclease protection. At the protein level, specific binding with ${ }^{125} \mathrm{I}\left[\mathrm{T}_{3}\right]$ was measured in these bovine cells yielding a $K_{\mathrm{d}}$ of $200 \mathrm{pmol} / 1$ and a $\mathrm{B}_{\max }$ of $5.6 \mathrm{pmol} / \mathrm{mg}$ protein (Hu et al. 1994). The human endothelial cell line ECV304 expresses mRNAs for TR $\alpha 1, \operatorname{TR} \alpha 2$ and $\operatorname{TR} \beta 1$ as measured by Northern blot and in situ hybridization analysis (Dietrich et al. 1997). In these cells increased intercellular adhesion molecule-1 mRNA expression was observed within hours after stimulation with $T_{3}$. In 
cultured primary human umbilical vein endothelial cells (HUVECs) (peri)nuclear and cytoplasmic staining of TR $\beta 1$ was found as well as increased expression of both mRNA and protein for endothelin-1 (ET-1), von Willebrand factor (vWF) and fibronectin after 13 days stimulation with $\mathrm{T}_{3}$ (Baumgartner-Parzer et al. 1997). Recently, Lansink et al. (1998) studied human microvascular endothelial cells derived from penile foreskin with an RT-PCR technique (using common primers for both $\operatorname{TR} \alpha 1$ and $\operatorname{TR} \alpha 2$ ) and found $\operatorname{TR} \alpha$ and $\operatorname{TR} \beta 1 \mathrm{mRNA}$ expression.

To explore the possibility of using the immortalized HUVEC line ECRF24 as a model for the interaction of thyroid hormone and endothelium, we studied TR isoform expression in these cells in a more quantitative manner using a real-time PCR technique. In addition, we performed Scatchard analysis, Western blotting and immunocytochemistry to study TR isoform protein expression and looked for $\mathrm{T}_{3}$-induced ET-1 and vWF expression (postreceptor effect).

\section{Materials and Methods}

\section{Materials}

RPMI 1640 (with Hepes and glutamine), Medium 199 (M199) (with $\mathrm{Na}_{2} \mathrm{HCO}_{3}$ and glutamine), human serum, L-glutamine, antibiotics/antimycotics (penicillinstreptomycin-fungizone) and trypsin/versene (EDTA) were purchased from Bio Whittaker, Walkersville, MD, USA. Geneticin sulphate (G418) was obtained from Gibco, Paisley, Scotland. 3,5,3'-Triidothyronine $\left(\mathrm{T}_{3}\right)$ was obtained from Henning $\mathrm{GmbH}$, Berlin, Germany, $\left[{ }^{125} \mathrm{I}_{\mathrm{T}} \mathrm{T}_{3}\right.$ (specific activity $2200 \mathrm{Ci} / \mathrm{mmol}$ ) from New England Nuclear, Boston, MA, USA. Culture flasks were from Costar Corporation, Cambridge, MA, USA. Gelatin (from swine skin type 1) was from Sigma, St Louis, MO, USA.

Polyclonal antisera, directed against synthetic TRisoform-specific ( $\alpha 1, \alpha 2$ and $\beta 1)$ peptides, coupled to keyhole limpet haemocyanin, were raised by immunization of New Zealand White rabbits (Eurogentec, Seraing, Belgium). Specificity of the antisera was tested by preimmune staining, preadsorption of the antisera with homologous antigen and by Western blots (C L Vuyst, U A Unmehopa, J M Bisselink, A A Sluiter, O Bakker, W M Wiersinga, D F Swaab \& E Fliers, unpublished observations).

\section{Cell culture}

HUVECs (ECRF24), immortalized using an amphotrophic, replication-deficient retrovirus containing the E6/E7 genes of human papilloma virus (a kind gift of
Dr R Fontijn, Department of Biochemistry, Academic Medical Centre, Amsterdam) (Fontijn et al. 1995), were cultured in $75 \mathrm{~cm}^{2}$ flasks coated with $1 \%$ gelatin and maintained at $37{ }^{\circ} \mathrm{C}$ in $5 \% \mathrm{CO}_{2}$. Culture medium consisted of equal volumes of RPMI 1640 (with Hepes and glutamine) and M199 (with $\mathrm{Na}_{2} \mathrm{HCO}_{3}$ and glutamine) containing $20 \%(\mathrm{v} / \mathrm{v})$ heat-inactivated human serum, glutamine $(2 \mathrm{mM})$, penicillin $(100 \mathrm{U} / \mathrm{ml})$, streptomycin $(100 \mu \mathrm{g} / \mathrm{ml})$, amphotericin B $(0 \cdot 25 \mu \mathrm{g} / \mathrm{ml})$ and $\mathrm{G} 418$ $(100 \mu \mathrm{g} / \mathrm{ml})$. Confluent cells were split after treatment with trypsin $(500 \mathrm{mg} / \mathrm{l}) /$ EDTA $(200 \mathrm{mg} / \mathrm{l})$. Cell viability was assessed by trypan blue exclusion.

The levels of free $T_{3}$ were measured in the culture medium using a Delfia free $\mathrm{T}_{3}$ time-resolved fluoroimmunoassay (Wallac, Perkin-Elmer, Finland).

\section{Assay of TR $m R N A$}

Confluent ECRF24 cells were grown in six-well plates. Total cellular RNA was isolated using Tri-Pure reagent (Roche Molecular Biochemicals, Mannheim, Germany) which was then reverse transcribed using random primers and a first-strand cDNA synthesis kit (AMV) (Roche Molecular Biochemicals). Real-time PCR reactions were performed in a LightCycler (Roche Molecular Biochemicals) in a $20 \mu$ volume. Detection was in the SYBR Green I format using the LightCycler FastStart DNA master SYBR Green I kit with the following program: $10 \mathrm{~min}$ $95{ }^{\circ} \mathrm{C}$ to activate the polymerase followed by 45 cycles of 0 s $95{ }^{\circ} \mathrm{C}, 5 \mathrm{~s} 52{ }^{\circ} \mathrm{C}, 10 \mathrm{~s} 72{ }^{\circ} \mathrm{C}$. Products were identified by their melting curve and by gel electrophoresis. Primer sequences and standards were as described (Bakker et al. 1998). Standards were added in the range of 1000 to $0 \cdot 1$ attograms $(\mathrm{ag}) / 20 \mu \mathrm{l}$. Standard curves were linear over this range and in all three cases had an $r=1.00$. The amount of isoform-specific mRNA molecules per cell was estimated taking into account a cDNA synthesis efficiency of about $30 \%$ and an average value of 20 pg total RNA per cell.

\section{Assay of TR protein}

Scatchard analysis Isolation of endothelial cell nuclei was performed by twice washing confluent ECRF24 cells with ice-cold PBS. The adherent cells were removed by scraping with a rubber policeman. Cells were taken in solution A (Tris $20 \mathrm{mM}, \mathrm{CaCl}_{2} 2 \mathrm{mM}, \mathrm{MgCl}_{2} 1 \mathrm{mM}$, glycerol $5 \%(\mathrm{v} / \mathrm{v})$, sucrose $0.25 \mathrm{M}, \mathrm{pH} 7 \cdot 6)$ and centrifuged at $500 \mathrm{~g}$. The cell pellet was lysed in solution A containing $0 \cdot 5 \%$ Triton X-100, again centrifuged at $500 \mathrm{~g}$ and subsequently homogenized in solution $\mathrm{A}$. Nuclei were harvested after centrifugation at $500 \mathrm{~g}$ and suspended into solution B (Tris $20 \mathrm{mM}$, glycerol $5 \%$, sucrose $0.25 \mathrm{M}$, EDTA $1 \mathrm{mM}, \mathrm{NaCl} 50 \mathrm{mM}, \mathrm{pH}$ 7·6). 
Freshly prepared nuclear suspension $(0.25$ to $0.1 \mathrm{ml})$ was incubated in solution B with $11-15 \mathrm{fmol}\left[{ }^{125} \mathrm{I}\right] \mathrm{T}_{3}$ in the presence of $5 \mathrm{mM}$ dithiothreitol for $2 \mathrm{~h}$ at $22{ }^{\circ} \mathrm{C}$ in a shaking water bath. Total volume was $0.5 \mathrm{ml}$, and all incubations were done in triplicate. The incubation was stopped by chilling the samples on ice; thereafter the nuclei were pelleted $\left(4{ }^{\circ} \mathrm{C}, 500 \mathrm{~g}\right)$ and washed twice with solution B containing $0.5 \%$ Triton X-100. Specific binding was calculated by subtracting the radioactivity remaining with the nuclear pellet of parallel incubations containing an excess $\left(10^{-6} \mathrm{M}\right)$ of non-radioactive $\mathrm{T}_{3}$. To determine the association constant $\left(K_{\mathrm{a}}\right)$ and maximum binding capacity $(\mathrm{MBC})$ of the binding of $\mathrm{T}_{3}$ to the nuclear receptors, Scatchard analysis was performed. To this end increasing amounts of non-radioactive $T_{3}$ were added to the test tubes. Using the DNA-binding fluorochrome Hoechst 33258 the amount of DNA per test tube was measured (Gallagher 1995). The number of binding sites per cell was calculated assuming one $T_{3}$ binding site per TR and an average DNA content per human cell of $6 \mathrm{pg}$.

Western blotting ECRF24 cells were homogenized in $0.25 \mathrm{M}$ sucrose containing complete-protease inhibitor (Roche Molecular Biochemicals). Of this whole cell extract, $30 \mu \mathrm{g}$ were loaded onto a 10\% SDS-PAGE. After blotting (BA45; Schleicher and Schuell, Dassel, Germany) the blot was blocked in 5\% non-fat dried milk in PBS for $1 \mathrm{~h}$ at room temperature. TR-isoform-specific rabbit polyclonal antisera in the same buffer were incubated for a further hour. Bands were visualized using goat anti-rabbit conjugated to horseradish peroxidase and LumiLight ${ }^{\text {Plus }}$ substrate (Roche Molecular Biochemicals). Average exposure time on the Lumilmager (Roche Molecular Biochemicals) was $5 \mathrm{~min}$.

Immunocytochemistry Cells were grown on microscopic slides coated with gelatin. Before and after each of the following procedural steps, cells were washed twice with PBS. Fixation was performed with $4 \%$ paraformaldehyde for $15 \mathrm{~min}$. After blocking for $30 \mathrm{~min}$ with $10 \%$ normal goat serum in PBS ( $\mathrm{pH} 7 \cdot 4$ ) with $0.5 \%$ Triton $\mathrm{X}-100$, the TR-isoform-specific rabbit polyclonal antisera in 10\% normal goat serum in PBS with $0.5 \%$ Triton X-100 were added. Incubation was at room temperature for $60 \mathrm{~min}$. Incubation with the second antibody, goat anti-rabbit IgG conjugated to alkaline phosphatase, was at room temperature for $60 \mathrm{~min}$. The $\mathrm{pH}$ was raised by incubation in buffer containing $0 \cdot 1 \mathrm{M}$ Tris, $0 \cdot 1 \mathrm{M} \mathrm{NaCl}$ and $50 \mathrm{mM} \mathrm{MgCl}_{2}(\mathrm{pH} \mathrm{9} 2$ ) for $10 \mathrm{~min}$. Nitro blue tetrazolium/5-bromo-4 chloro-3-indolyl phosphate (Roche Molecular Biochemicals)+levamisole (Sigma), to inhibit endogenous alkaline phosphatase, were added for $20 \mathrm{~min}$. Slides were covered with Kaiser glycerine medium and dried overnight. Detection of
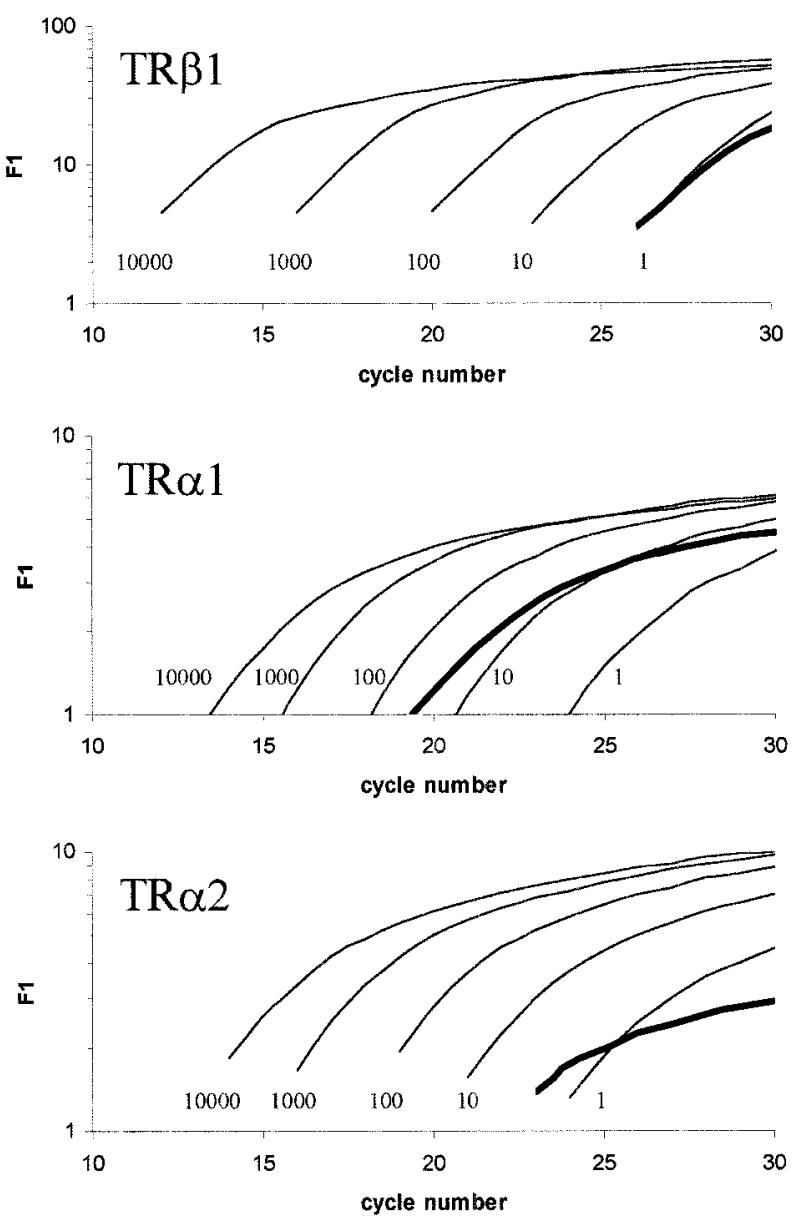

Figure 1 TR isoform mRNA levels in immortalized ECRF24 HUVECs. The plots show the fluorescent signal (F1), as measured using the LightCycler, of the standard curves (thin black lines) which were used to calculate the amount of RNA per cell in the sample (thick black line). The numbers at the standard curves indicate the mRNA amount per cell equivalent.

positively stained cells was with a light microscope. As a control, slides incubated with normal rabbit serum were used.

\section{ET-1 and vWF secretion by ECRF24 cells}

Cells were cultured in six-well plates until they were confluent. Then regular medium was replaced by serumfree medium for $24 \mathrm{~h}$. Subsequently ET-1 production was measured in cell supernatant in relation to the amount of cells $\left(0 \cdot 25-, 0 \cdot 50-\right.$ and $1 \cdot 0 \times 10^{6}$ cells $)$, in relation to duration of culture $(4,8,12$ and $24 \mathrm{~h})$ and in relation to the amount of $\mathrm{T}_{3}$ added $\left(0 \mathrm{M}, 10^{-10}-10^{-6} \mathrm{M}\right)$. Prior to ET-1 measurement, cell supernatant was extracted with C2 solid phase minicolumns (Amprep; Amersham International plc, Little Chalfont, Bucks, UK ) according to the manual of the manufacturer. ET-1 was measured 


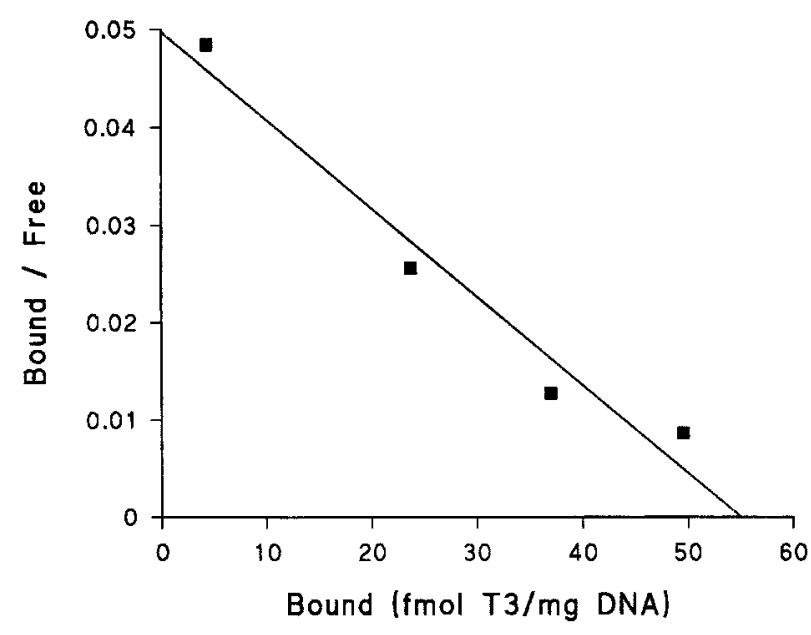

Figure 2 Scatchard plot of $\mathrm{T}_{3}$ binding to nuclei of immortalized ECRF24 HUVECs. Equation of regression line: $y=0.498-0.009 x$, $r=-0.978, P=0.02$.

with a quantitative colorimetric two site immunoenzymetric 'sandwich' ELISA (Biotrak Endothelin-1 ELISA system, Amersham International) with a detection limit of $1 \mathrm{fmol} /$ well. vWF was measured using an in-house sandwich-ELISA using rabbit anti-human vWF (A082; Dako, Copenhagen, Denmark) and rabbit anti-human vWF peroxidase conjugate (P226; Dako) with a pool of 100 normal human samples as a standard.

\section{Results}

TR $m R N A s$

We used real-time PCR to quantify the mRNAs encoding for the different isoforms of the TR in immortalized human endothelial cells. We found that there were about $1500 \mathrm{ag} / 20 \mu \mathrm{TR} \alpha 1,160 \mathrm{ag} / 20 \mu \mathrm{l} \mathrm{TR} \alpha 2$ and $8 \mathrm{ag} / 20 \mu \mathrm{l}$ TR $\beta 1$. Calculating the approximate number of mRNA molecules per cell from these figures gives an estimate of at least 50 molecules per cell for TR $\alpha 1$, five for $\operatorname{TR} \alpha 2$ and two for TR $\beta 1$ (Fig. 1).

\section{TR proteins}

Figure 2 shows the Scatchard plot of nuclear $\mathrm{T}_{3}$ binding. The non-specific binding of $\left[{ }^{125} \mathrm{I}\right] \mathrm{T}_{3}$ was $0.71 \%$ and the specific binding was $4 \cdot 57 \%$ ( $580 \mu \mathrm{g}$ DNA/tube). Specific $\mathrm{T}_{3}$ binding increased linearly with the amount of nuclei (DNA) added. The MBC for $\mathrm{T}_{3}$ of the endothelial cell nuclei was $55.2 \mathrm{fmol} \mathrm{T}_{3} / \mathrm{mg}$ DNA, the association constant $K_{\mathrm{a}}$ of $\mathrm{T}_{3}$ was $8 \times 10^{9} \mathrm{l} / \mathrm{mol}\left(K_{\mathrm{d}} 125 \mathrm{pmol} / \mathrm{l}\right)$. The number of TR protein molecules was calculated as approximately $200 /$ cell.

Immunocytochemistry revealed perinuclear staining with anti-TR $\beta 1$, anti-TR $\alpha 2$ and anti-TR $\alpha 1$ (Fig. 3). No
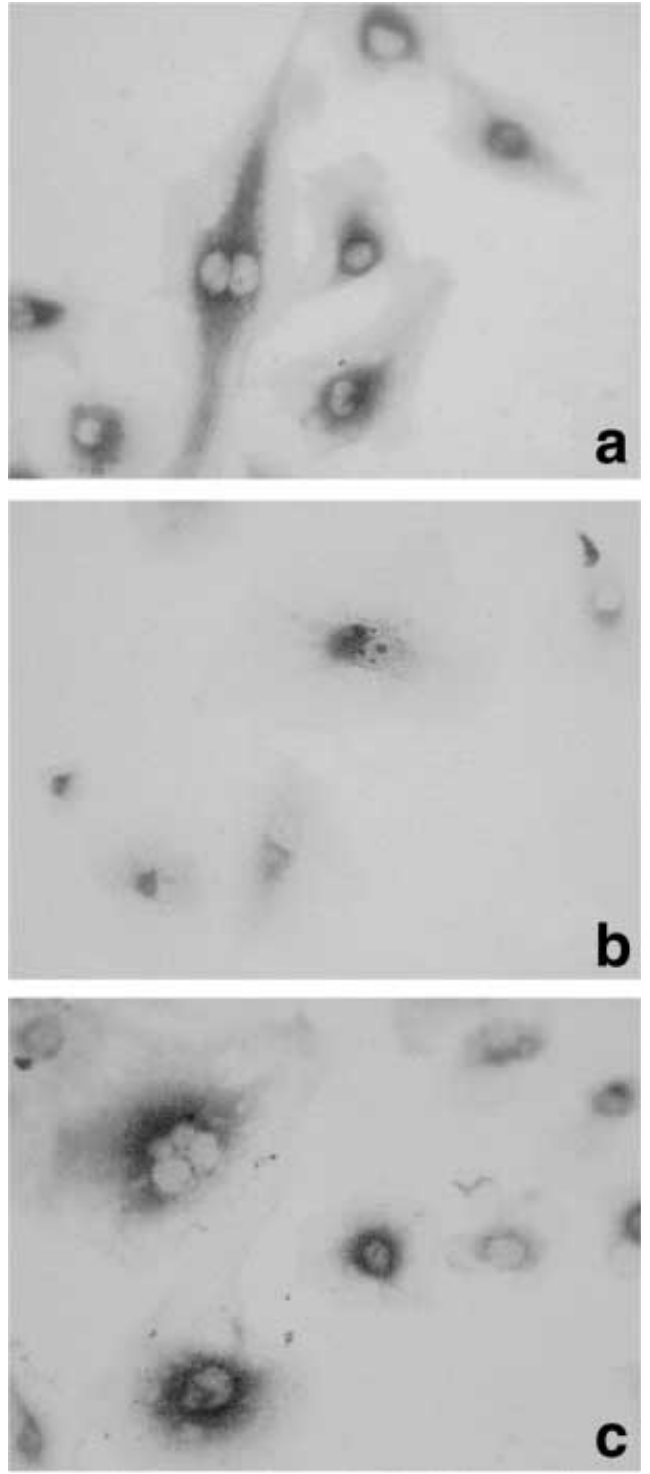

Figure 3 The expression of TR proteins in immortalized ECRF24 HUVECs. Cells were grown on slides and incubated with (a) TR $\beta 1$-, (b) TR $\alpha 2$ - and (c) TR $\alpha 1$-specific antipeptide rabbit polyclonal antibodies. For all isoforms perinuclear staining is observed.

staining was observed with the respective pre-immune sera (data not shown).

The Western blot provided further evidence for the presence of the different TR isoforms. Bands corresponding to the expected sizes of the TR $\alpha 1$, TR $\alpha 2$ and TR $\beta 1$ isoforms, 47, 52 and $55 \mathrm{kDa}$ respectively, were observed (Fig. 4).

\section{ET-1 and $v W F$ production}

ET-1 production increased in proportion to the amount of cells $\left(0 \cdot 25-1 \cdot 0 \times 10^{6} /\right.$ well $)$ from $6 \cdot 4$ to $20 \cdot 4 \mathrm{fmol} /$ well 


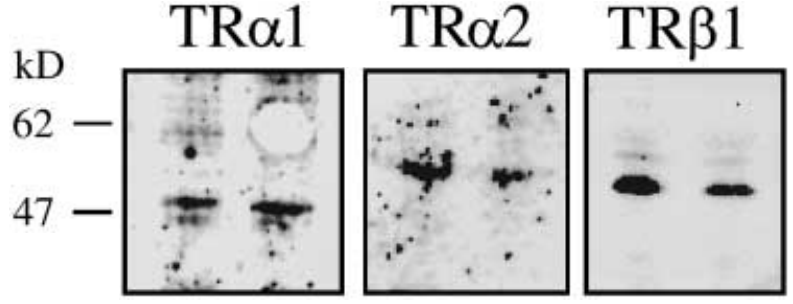

Figure 4 Western blot of whole cell extracts of ECRF24 cells. Parts of the blot were incubated with TR $\alpha 1$-, TR $\alpha 2$ - and TR $\beta 1$-specific antipeptide rabbit polyclonal antibodies. Bands were detected using LumiLight ${ }^{\text {Plus }}$ horseradish peroxidase substrate. Their positions correspond to the expected length of the TR $\alpha 1, T R \alpha 2$ and TR $\beta 1$ isoforms, at 47, 52 and 55 kDa respectively.

when cultured for $4 \mathrm{~h}$. In time-course experiments ET-1 production increased from $\approx 20 \mathrm{fmol} /$ well at $4 \mathrm{~h}$ to $\approx 70 \mathrm{fmol} /$ well at $24 \mathrm{~h}$. The addition of increasing amounts of $\mathrm{T}_{3}$ had no influence on ET-1 production at any time-point compared with cultures in the absence of $\mathrm{T}_{3}$ (Fig. 5a). vWF production by ECRF24 cells increased with time but no effect of $\mathrm{T}_{3}$ was observed (Fig. 5b). To check that the lack of effect of $\mathrm{T}_{3}$ was not due to decreased availability of the hormone, we measured free $T_{3}$ in our culture medium. Under basal conditions this was about $4 \mathrm{pmol} / 1$ and when $10^{-6} \mathrm{M} \mathrm{T}_{3}$ was added to the culture medium $>70 \mathrm{pmol} / 1$ free $\mathrm{T}_{3}$ were measured.

\section{Discussion}

Using real-time PCR we were able to quantify for the first time the mRNA for TR $\alpha 1$ (50 copies/cell), TR $\alpha 2$ (five copies/cell) and TR $\beta 1$ (two copies/cell) isoforms expressed by the immortalized HUVEC line ECRF24. We found more TR $\alpha 1$ and TR $\alpha 2$ than TR $\beta 1$ mRNA, which is in accordance with previous results on the TR isoform mRNAs in bovine aortic endothelial cells ( $\mathrm{Hu}$ et al. 1994). The amount of mRNA for the TR $\alpha 1$ (acting in a positive fashion on gene expression) appeared to be 10-fold higher than for the TR $\alpha 2$ (acting in a negative fashion on gene expression), which suggests that these endothelial cells are potentially $\mathrm{T}_{3}$ responsive when the corresponding proteins are translated.

At the protein level, TR $\alpha 1, \operatorname{TR} \alpha 2$ and TR $\beta 1$ were all expressed, as evident from both immunocytochemistry and Western blots. The discrepancy between the low amount of mRNA for the TR $\beta 1$ and the apparent presence of TR $\beta 1$ protein is similar to that found for TR $\beta 2$ in rat liver (Ercan-Fang et al. 1996). One possible explanation could be a short half-life of the TR $\beta 1$ mRNA as was indeed suggested for the TR $\beta 2 \mathrm{mRNA}$ /protein discrepancy (Ercan-Fang et al. 1996).

The perinuclear staining pattern of the TR $\beta 1$ is in accordance with the site of action of the TRs, binding to a
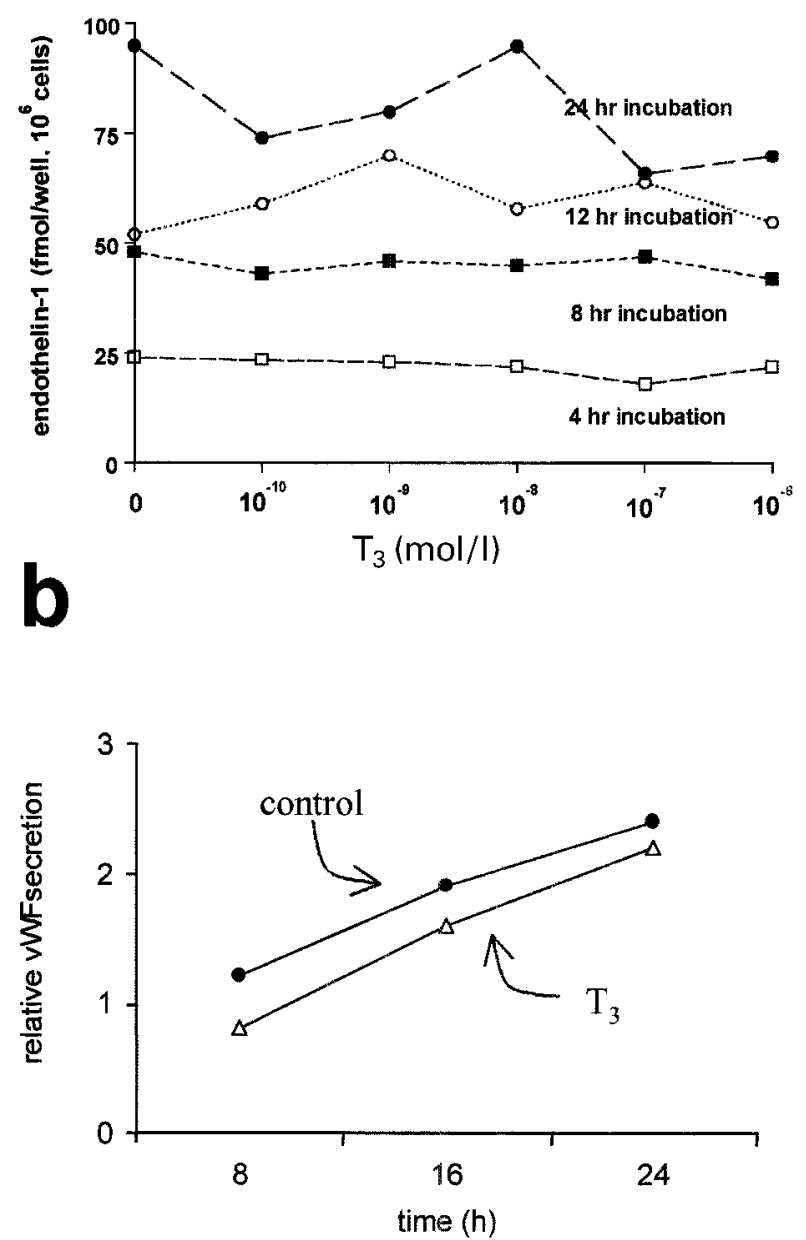

Figure 5 Postreceptor effects in immortalized ECRF24 HUVECs. (a) ET-1 production in relation to the duration of incubation $(4,8$, 12 and $24 \mathrm{~h}$ ) and in relation to the amount of $\mathrm{T}_{3}$ added to the culture medium. (b) vWF production in relation to time and $T_{3}$ (at $10^{-6} \mathrm{M}$, triangles). Control incubations are shown by the black dots.

their thyroid hormone response elements (TREs) on the DNA. Perinuclear and cytoplasmic staining of TRs has been reported in other studies on TR localization in both endothelial cells (Sellitti et al. 1985, Baumgartner-Parzer et al. 1997) and other cell types like hepatocytes (Chamba et al. 1996), extra-ocular muscle fibres (Schmidt et al. 1992) and anterior pituitary cells (Yen et al. 1992).

No increase in ET-1 or vWF production by ECRF24 cells after short-term exposure (maximum $24 \mathrm{~h}$ ) to $\mathrm{T}_{3}$ was observed by us. Baumgartner-Parzer et al. (1997) reported that HUVECs were $\mathrm{T}_{3}$ responsive with regard to both ET-1 and vWF production. However, this was seen only after prolonged culturing (13 days), not after short-term 
incubation $(24 \mathrm{~h})$. Other studies did demonstrate effects on ET-1 after short-term incubations with $\mathrm{T}_{3}$. In rat aortic endothelial cells a slight increase (+17\%) in ET-1 secretion after a 3-12 $\mathrm{h}$ incubation with $\mathrm{T}_{3}$ at $10^{-6} \mathrm{M}$ and an increase of adrenomedullin mRNA after $3 \mathrm{~h}$ incubation with $10^{-6} \mathrm{M} \mathrm{T}_{3}$ have been found (Imai et al. 1995, Isumi et al. 1998). Furthermore, in bovine pulmonary artery cells a 2-fold increase in angiotensin-converting enzyme activity after $48 \mathrm{~h}$ incubation with $10^{-6} \mathrm{M} \mathrm{T}_{3}$ has been reported (Krulewitz et al. 1984). One reason why we did not observe an effect on ET-1 in the ECRF24 cells could be the venous origin of our cells, in contrast to the other short-term studies, which used endothelial cells of arterial origin.

Assuming that a $\mathrm{T}_{3}$-responsive gene contains one TRE and taking into account an average $K_{d}$ of about $10^{-9}$ $\mathrm{mol} / \mathrm{l}$ for a nuclear factor binding to its specific binding site (Bakker \& Parker 1991), one can estimate that at least $1000 \mathrm{TR}$ molecules per cell are needed to mediate $\mathrm{T}_{3}$ responsiveness. Our Scatchard analysis showed that only $\approx 200$ TR molecules were available per endothelial cell, which is far below this amount. The $K_{\mathrm{d}}$ of $125 \mathrm{pmol} / 1$ was in accordance with the magnitude of the $K_{\mathrm{d}}$ measured in bovine aortic endothelial cells (Hu et al. 1994). Comparison of the figure of 200 sites per ECRF24 cell with that in rat liver tissue, which has about 4000 TR sites/cell (Ercan-Fang et al. 1996), also suggests that the number of TR sites per endothelial cell is probably not enough to mediate $\mathrm{T}_{3}$ effects. Similar numbers of TRs have been found in human peripheral blood lymphocytes and placenta (Banovac et al. 1986, Matzen et al. 1989) but postreceptor effects have not been reported for these cells either.

In conclusion, the immortalized HUVEC line ECRF24 expresses TR $\alpha 1$ and TR $\alpha 2$ isoforms at both the mRNA and protein level, whereas for the TR $\beta 1$ there appears to be a discrepancy between its mRNA and protein levels. Although $\approx 200$ TR sites per cell were found, we conclude that this amount is probably insufficient to mediate genomic $\mathrm{T}_{3}$-induced effects, as was evident from the absence of an increase of ET-1 or vWF secretion upon incubation with $\mathrm{T}_{3}$.

\section{Acknowledgement}

The ECRF24 cell line was a kind gift from Ruud Fontijn (Department of Biochemistry, Academic Medical Centre, Amsterdam).

\section{References}

Bakker O \& Parker MG 1991 CAAT/enhancer binding protein is able to bind to ATF/CRE elements. Nucleic Acids Research 19 1213-1217.
Bakker O, Razaki H, de Jong J, Ris Stalpers C \& Wiersinga WM 1998 Expression of the $\alpha 1, \alpha 2$, and $\beta 1 \mathrm{~T}_{3}$-receptor mRNAs in the fasted rat measured using competitive PCR. Biochemical and Biophysical Research Communications 242 492-496.

Banovac K, Ryan EA \& O'Sullivan MJ 1986 Triiodothyronine $\left(\mathrm{T}_{3}\right)$ nuclear binding sites in human placenta and decidua. Placenta 7 543-549.

Baumgartner-Parzer SM, Wagner L, Reining G, Sexl V, Nowotny M, Muller M, Brunner M \& Waldhausl W 1997 Increase by triiodothyronine of endothelin-1, fibronectin and von Willebrand factor in cultured endothelial cells. Journal of Endocrinology 154 231-239.

Chamba A, Neuberger J, Strain A, Hopkins J, Sheppard MC \& Franklyn JA 1996 Expression and function of thyroid hormone receptor variants in normal and chronically diseased human liver. Journal of Clinical Endocrinology and Metabolism 81 360-367.

Cines DB, Pollak ES, Buck CA, Loscalzo J, Zimmerman GA, McEver RP, Pober JS, Wick TM, Konkle BA, Schwartz BS, Barnathan ES, McCrae KR, Hug BA, Schmidt AM \& Stern DM 1998 Endothelial cells in physiology and pathophysiology of vascular disorders. Blood 91 3527-3561.

Dietrich JB, Kuchler-Bopp S, Boutillier S, Ittel ME, Reeber A, Zaepfel M, Delaunoy JP \& Vincendon G 1997 Expression of thyroid hormone receptors alpha and beta- 1 messenger RNAs in human endothelial cells. The $T_{3}$ hormone stimulates the synthesis of the messenger RNA of the intercellular adhesion molecule. Cellular and Molecular Biology 43 1205-1212.

Ercan-Fang S, Schwartz HL \& Oppenheimer JH 1996 Isoformspecific 3,5,3'-triiodothyronine receptor binding capacity and messenger ribonucleic acid content in rat adenohypophysis: effect of thyroidal state and comparison with extrapituitary tissues. Endocrinology 137 3228-3233.

Fontijn R, Hop C, Brinkman HJ, Slater R, Westerveld A, Van Mourik JA \& Pannekoek H 1995 Maintenance of vascular endothelial cell-specific properties after immortalization with an amphotrophic replication-deficient retrovirus containing human papilloma virus 16 E6/E7 DNA. Experimental Cell Research 216 199-207.

Gallagher SR 1995 Quantitation of DNA and RNA with absorption and fluorescence spectroscopy. DNA detection using the DNAbinding fluorochrome Hoechst 33258. In Current Protocols in Molecular Biology, edn 1, A.3D.3, Suppl 28. Eds FM Ausubel, R Brent \& RE Kingston. New York: John Wiley \& Sons, Inc.

Hu RM, Wu LM, Frank HJL, Pedram A \& Levin ER 1994 Insulin stimulates thyroid hormone receptor $\alpha$ gene expression in cultured bovine aortic endothelial cells. Molecular and Cellular Endocrinology 103 65-71.

Imai T, Hirata Y, Iwashina M \& Marumo F 1995 Hormonal regulation of rat adrenomedullin gene in vasculature. Endocrinology $1361544-1548$.

Isumi Y, Shoji H, Sugo S, Tochimoto T, Kangawa K, Matsuo H \& Minamino N 1998 Regulation of adrenomedullin production in rat endothelial cells. Endocrinology 139 838-846.

Krulewitz AH, Baur WE \& Fanburg BL 1984 Hormonal influence on endothelial cell angiotensin-converting enzyme activity. American Journal of Physiology 247 163-168.

Lansink M, Koolwijk P, van Hinsbergh V \& Kooistra T 1998 Effect of steroid hormones and retinoids on the formation of capillary-like tubular structures of human microvascular endothelial cells in fibrin matrices is related to urokinase expression. Blood 92 927-938

Lazar MA 1993 Thyroid hormone receptors: multiple forms, multiple possibilities. Endocrine Reviews 14 184-193.

Matzen LE, Kvetny J \& Pedersen KK 1989 TSH, thyroid hormones and nuclear-binding of $\mathrm{T}_{3}$ in mononuclear blood cells from obese and non-obese women. Scandinavian Journal of Clinical Laboratory Investigation 49 249-253. 
Polikar R, Burger AG, Scherrer U \& Nicod P 1993 The thyroid and the heart. Circulation 87 1435-1441.

Schmidt ED, Van der Gaag R, Ganpat R, Broersma L, de Boer PA, Moorman AF, Lamers WH, Wiersinga WM \& Koornneef $\mathrm{L}$ 1992 Distribution of the nuclear thyroid hormone receptor in extraocular and skeletal muscles. Journal of Endocrinology 133 $67-74$.

Sellitti DF, Oliver C \& Latham KR 1985 Antibodies to nuclear thyroid hormone-binding proteins. Experimental Cell Research 158 223-236.
Vane JR, Änggård EE \& Botting RM 1990 Regulatory functions of the vascular endothelium. New England Journal of Medicine 323 27-36.

Yen PM, Sunday ME, Darling DS \& Chin WW 1992 Isoform-specific thyroid hormone receptor antibodies detect multiple thyroid hormone receptors in rat and human pituitaries. Endocrinology 130 1539-1546.

Received 23 October 2000

Accepted 31 October 2000 